\title{
EVALUATION OF LONG-TERM CHANGES MORPHOMETRY OF LAKE KISEZERS
}

\author{
Janis Dumpis ${ }^{1,2}$, Ainis Lagzdiņ $\check{s}^{1}$ \\ ${ }^{1}$ Latvia University of Life Sciences and Technologies, Latvia \\ ${ }^{2}$ Institute of Food Safety, Animal Health and Environment 'BIOR', Latvia \\ janisdumpis94@gmail.com
}

\begin{abstract}
This study is important to contribute morphometry researches and give an example of how to accomplish studies about lakes. The aim of the study is to use the latest technology to determine the morphometric parameters and their variability compared to the previous research results. Research focuses not only on local water body morphometry and bathymetry, and their influencing factors, but also deals with methodological issues regarding measurements of morphometric characteristics and data interpretation as well as state of the art visualization of results. On many occasions, there is a lack of research on morphometry of water bodies or they have taken place in the last century, which has led to the use of obsolete research methods in modern morphometry studies that do not produce the results of a high level of detail. The aim of the study is to use the latest technology to determine the morphometric parameters and their variability compared to the previous research results. The study consists of analysis of the literature on morphometry, methodology used in bathymetry studies, history of research, research methods used in the previous studies. The research object is Lake Kisezers including its morphometry, bathymetry, and influencing factors. The results of the study show that morphometric parameters of Kisezers differ from the results of previous studies. The results of the study confirm that Lake Kisezers is exposed to various influencing factors, mainly anthropogenic. The main factor influencing morphometry and hydrological regime in Kisezers is the water level fluctuations influaced by Riga Hydroelectric Power Plant.
\end{abstract}

Key words: Lake Kisezers, morphometry, bathymetry, water level fluctuations.

\section{Introduction}

The bathymetry and morphometrics are among the most important lake characterization indicators that provide necessary information on the status of a water body and its development in relation to its place and changes in the hydrological regime. The morphometric parameters of the lake are influenced by the location, origin, natural conditions, other water bodies and watercourses of the lake catchment area, as well as the anthropogenic impact (J.G. Tundisi \& T.M. Tundisi, 2012). By interacting with these factors, a lake can change over a shorter or longer period of time (Slaucītājs, 1935). Hydrologic changes in the catchment area have a significant impact on the water body (Glazačeva, 2004). When determining changes in morphometry, it is possible to determine to what extent anthropogenic effects have altered the ecosystem of a lake (Agnieszka, Adam, \& Kurzyca, 2011). Morphometry is a quantifiable parameter to assess how to use and manage a lake (J.G. Tundisi \& T.M. Tundisi, 2012). The identification of bathymetry is important for depth monitoring and determination of changes in morphometry (Jawak \& Luis, 2015). Determination of lake's depth is important to understand flows of nutrients and water body productivity (Leinerte, 1992).

Lake Kisezers is a component of a complex hydrological system where water level measurements have been carried out, in a long-term at several observation stations that allows to precisely evaluate water level fluctuations in the water body. There is inconsistent historical information on its morphometric characteristics available, which leads to the assumption that the available bathymetric map does not reflect the current situation. Perhaps the map used to calculate the morphometric characteristics of the published sources has been kept as a secret during the Soviet Union time and has not been published. When choosing Lake Kisezers as an object of the research, attention was also paid to the fact that Lake Kisezers is defined as a waterbody at risk in Latvian legislation (LVG̣MC, 2014). In addition, Lake Kisezers is also referred to as the priority fish water. In order to set the ecological and chemical quality criteria for Lake Kisezers, it is necessary to identify its depths, as the average depth is a criterion after which lakes are classified according to their respective quality standards (Cabinet of Ministers ..., 2004). Being in the city, Lake Kisezers is an important recreational object, but it is also a subject to strong anthropogenic effects, such as wastewater discharges, where chemical compounds accelerate eutrophication processes.

Studies of morphometry in Latvian lakes started in the $20^{\text {th }}$ century. Already in $1909, \mathrm{~F}$. Ludwig performed a detailed morphometric description of several lakes in the vicinity of Riga (Kokorīte, 2007), with a total of 29 lakes (Spuris, 1968). The research of national significance in the 1920s - 1930s has been developed (number of lakes, areas, general limnologic surveys) by V. Ozolinşs, V. Zāns, A. Kursītis, L. Slaucītājs, P. Stakle, P. Nomals, M. Galenieks (Cimdiņš, 2001). In the 1950s, H. Sizov conducted the study in 21 lakes. During this study bathymetry, morphometry 
and classification of lakes have been done. The study has been unique because a boat has been used to measure the depth of water, rather than measurements taken from ice, as described in previous studies by authors (Сизов, 1959). In the 1950s, from 1943 until 1952 overall 20 Latvian lakes have been studied (Kumsāre, 1960; Cimdiņš, 2001). The methodology of Latvian research differs considerably from that of used in other countries. For example, bathymetry surveys have been conducted during the winter period measuring the depth of ice drilled pebbles instead of using an echo sounder. The measurement locations have been selected to cover the entire waterbody and represent its depth. The measurements were between 20 and $60 \mathrm{~m}$ apart. A. Tims was the first who studied Lake Kisezers (Slaucītājs, 1935). The results of our study differ substantially from the results obtained in 1882 by a hydrologist A. Tīms. The differences can be explained by lowering the water level of Lakes Lielais and Mazais Baltezers by $1.8 \mathrm{~m}$ due to the construction of the Gauja - Daugava Canal and the demolition of the mill of Bukulti (Slaucitājs, 1935). Analyzing the literature, it can be concluded that morphometry is usually determined from early $20^{\text {th }}$ century map. There is a lack of information on studies in the late $20^{\text {th }}$ and early $21^{\text {st }}$ century. In Latvia, there has been no study on morphometry and bathymetry of lakes using the latest technologies such as (computer software and echo sounders).

When determining changes in morphometry, it is possible to estimate to what extent anthropogenic effects have altered the ecosystem of a lake (Agnieszka, Adam, \& Kurzyca, 2011). Morphometry is quantifiable to assess how to use and manage a lake best(J.G. Tundisi \& T.M. Tundisi, 2012). Morphometry describes the size of a waterbody and implies application of remote sensing, field, and chamber working methods. Nowadays, geographic information systems are widely used for the analysis of geospatial information (Gilberto, Goncalves, \& Garcia, 2014). The accuracy of the morphometric measurements is determined by the scale of the cartographic material (Сизов, 1959), as well as the quality of the data of the waterbody and used equipment (Gilberto, Goncalves, \& Garcia, 2014), the location of the waterbody, the purpose of further usage of the research results. The identification of bathymetry is important for depth monitoring and determination of changes in morphometry (Jawak \& Luis, 2015). The bathymetric map is a source of several morphometric parameters that are measured. The newer and more qualitative data used to construct a bathymetric map, the more accurate the morphometric parameters are. Smaller intervals between the isobates provide a more detailed representation of the water body's bathymetry, which in turn gives more accurate results in morphometry studies. Overall, a higher degree of the bathymetric map may provide a more accurate determination of morphometric parameters (Hakanson, 1981).

Lake Kisezers is located on the seaside lowland, in the territory of Riga, in the Daugava river basin with lakes with a density of 0.038 lakes per $\mathrm{km}^{2}$ (Tidrikis, 1995). This lake is the 10th largest lake in Latvia. The lake has three islands (Tidrikis, 1995). The lake is oblong-shaped with a scalloped shoreline and several shallow bays (Kačalova, 1984). The water body is located in the Kisezers - Jugla lake district, location shown in Figure 1. in the far part of the lagoon of Littorina (Kačalova, 1984). Lake Kisezers, together with Lake Jugla, is located in one valley formed by the former Daugava river. Lake Kisezers is a permeable river-type lake (Slaucītājs, 1935; Stiebriņš, 2011). It is connected with Lakes Mazais and Lielais Baltezers, Lake Jugla and is a part of the DaugavaGauja hydrologic system. Geological research shows that Lake Kisezers, as well as Lake Jugla, Lielais and Mazais Baltezers were once a single waterbody - the Garciema Lagoon with inflow from both the Daugava and Gauja River. The description of Lake Kisezers in literature sources by $20^{\text {th }}$ century is mainly based on Kačalova, Kumsāre and Kundziñš in the book 'The Great Lakes in the Neighborhood of Riga'. The results are described in the $5^{\text {th }}$ Vol. (Kačalova, 1984), Vol. 2 of the Small Encyclopedia of the Latvian SSR (Pastors, 1968).

The gradual transformation of the hydrographic network of Riga and its neighborhood has been mainly driven by climate change. In the past, the hydrographic network changed only in natural processes, but after the city of Riga was established and expanded, the changes in the hydrographic network, among other things, also contributed to anthropogenic pressure (Stiebriņ̌š, 2011).

According to the author's visual observations, it can be concluded that the channels have frequent and rapidly changing water level, flow rate, and direction. As a result of wind floods, the water level can rise by more than $2 \mathrm{~m}$ or decrease by more than $1 \mathrm{~m}$. Due to the location of Lake Kisezers in a complex system, the lake is subject to anthropogenic and natural factors that affect the water body's morphometry and water level changes.

The aim of the study is to use the latest technology to determine the morphometric parameters and their variability compared to the previous research results. The following tasks were set for this study:

1. to develop a methodology for depth map design and fieldwork and evaluate its suitability for applications in future studies;

2. to collect depth data of Lake Kisezers in the fieldwork and develop Lake Kisezers bathymetric map based on the results of fieldwork, identify 


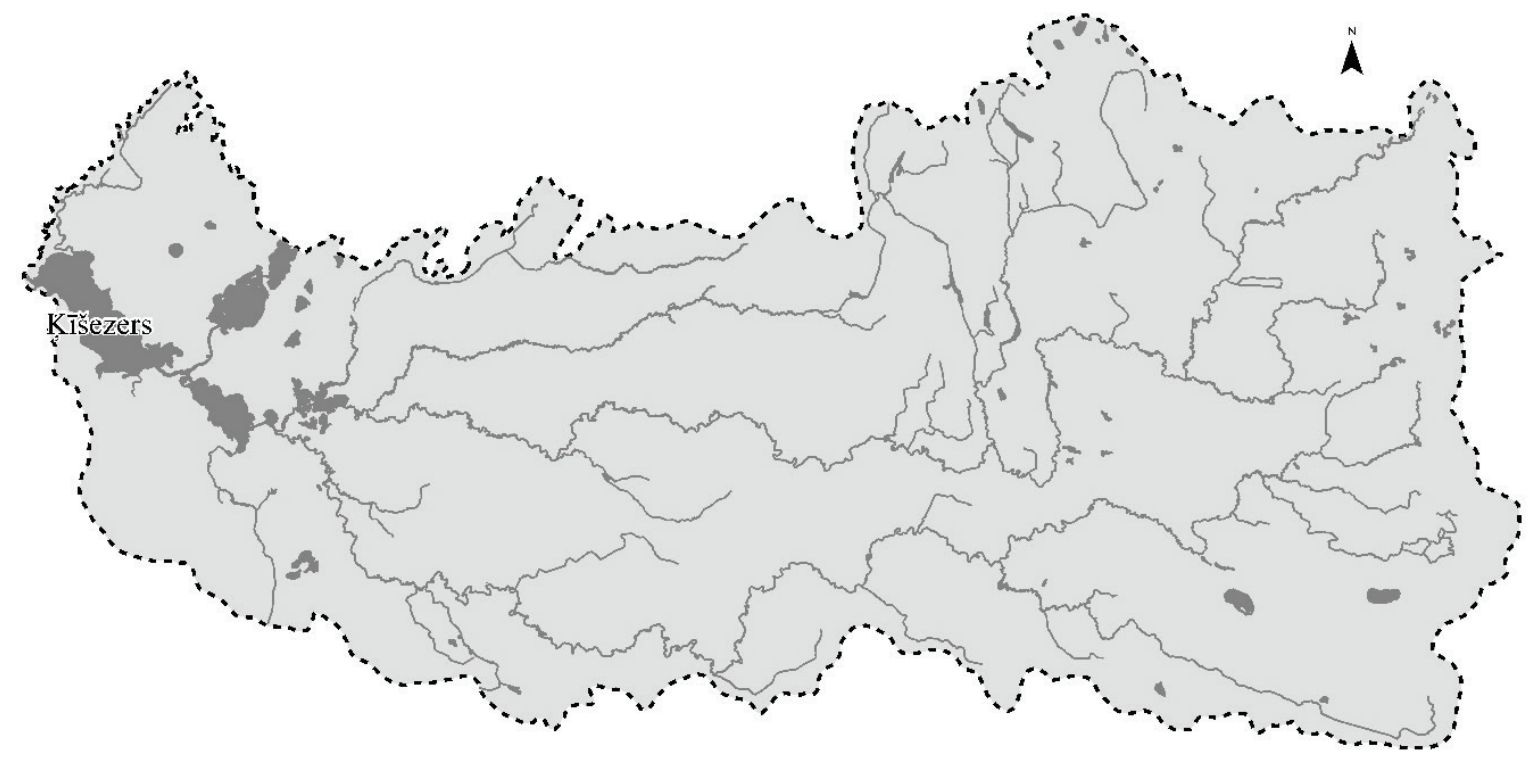

Legend

Waterbody/Watercourse

-... Catchment area

0

10

$20 \mathrm{~km}$

Figure 1. Study subject Lake Kisezers catchment area (For map construction used LVM GEO Map Browser free maps from The Latvian Geospatial Information Agency and Gis Latvia 10.2).

water bodies morphometrical parameters and compare the results with the information found in the literature.

\section{Materials and Methods}

The study uses the data from the fieldwork in 2017, which includes the data on Lake Kisezers depth measurements, the mapping of the surface overgrowth, the data of the coastline decryption. The obtained data were used in the construction of the bathymetric map, and furthermore of calculate and determine morphometric parameters and the watercourse shoreline inspection has been done. The study summarizes the water level data of the observation stations 'Ķ1̄̌̌ezers', 'Rīga', 'Daugavgrīva', 'Andrejosta', which were obtained from the Latvian Environment, Geology and Meteorology Centre Water level data is collected to assess how the water level between observation days changed and the data could be interconnected. Water level data to determine how fast the water level changes in the water body, which in turn alters all morphometric parameters.

Survey

The survey of Lake Kisezers was conducted on July 15, 16, 22, 23, 2017. The field works at Lake Kisezers were carried out in four days using a boat. In general, the depth measurements were made in about $50 \mathrm{~h}$. The length of the depth measurements was influenced by the boat with a maximum speed of 25 to $30 \mathrm{~km} \mathrm{~h}^{-1}$, the size of the waterbody, safety considerations (wave height, wind force, other floating craft). During the field work the estimation of the bathymetry of an embankment, the anthropogenic load was carried out by examining the shoreline of the water body and deciphering the changes and determining the location of the shoreline using GPS. Lake Kisezers was surveyed by moving around the perimeter of the lake with each circle away from the shore. Similarly, measurements can also be collected in the form of profiles (Sambuelli \& Bava, 2011), but it is slower because the boat needs to turn around every time the water body is crossed. By moving around the perimeter of the lake, the data record reduces the chance of error, as the boat draft changes with uneven speed, resulting in errors and more complex and time - consuming data editing.

When looking at a waterbody, it is necessary to choose a suitable inventory (Hakanson, 1981). Lowrance Hook 5 GPS was used for the depth data recording during the survey. The results of this survey were converted into the required formats (shp), processed, and edited. From the processed data, a highly detailed bathymetric map with isobates of $1 \mathrm{~m}$ depth change and every $2 \mathrm{~m}$ depth change was constructed. A bathymetric map with isobathic every $2 \mathrm{~m}$ depth change was used for morphometric calculations. During the survey of Lake Kisezers, anthropogenic impacts near the shoreline were assessed. 
For lake depth measurements and data acquisition, an engine equipped motorboat equipped with an echo sounder with a recording function and GPS is required. It is recommended to not take the record for more than a few hours, otherwise, the routes become too long and there is a greater chance that an error may occur in the echo record. The data from the Lake Kisezers survey takes 3.65 GB. For data recording, the echo sounder Lowrance Hook 5 with GPS and data recording function was used. Lake Kisezers was surveyed with a low - power motor boat for depth measurements Dulkan 400 with $7.45 \mathrm{~kW}$ Yamaha engine. The advantages of a low - power motorboat, in this case, are mainly fewer error areas requiring data editing. Such a boat is less damaging to the already significant anthropogenic load-bearing Lake Kisezers, due to its low fuel consumption, it produces fewer emissions.

The data from the fieldwork were processed, error areas have been edited, and corrections have been made in the immediate vicinity of the shoreline and in overgrown areas that may have hindered the echo rays, and thus depth information was read imprecisely. The depth measurements include a boat draft (Boiten, 2003 ), which is $25 \mathrm{~cm}$ in this case. The editing process included the conversion of each day's data, alignment to the water level of a given day, and addition of the echo proba draft $(25 \mathrm{~cm})$ to the results obtained. Depth measurements were all aligned to the average water level of $45.9 \mathrm{~cm}$ above sea level on the first day of observation (July 15). The results obtained for the second day of fieldwork were subtracted from $8.1 \mathrm{~cm}$ $(53.8 \mathrm{~cm})$. The results of the third field work day are added to $15.1 \mathrm{~cm}(30.8 \mathrm{~cm})$. The results of the fourth day are added to $22.5 \mathrm{~cm}(23.4 \mathrm{~cm})$.

A bathymetric map is constructed using field record data files in the sl2 format. Data records for each day are converted to shape file (shp) format using the MapCreator. Shp was edited and merged using ArcMap software of ESRI, summarized shp was converted to csv data format. Using ReefMaster card processing and interpolation tools, a bathymetric map with isobates every 1 and $2 \mathrm{~m}$ depth changes were constructed. ArcMap has been used in the final stages of creating a bathymetric card to design a map. In order to successfully create a bathymetric map, depth recording data in csv, shp, sl2 format, qualitatively marked coastline is required. The coastline can be used to determine the boundaries of the map interpolation. The analysis of the morphometric parameters was based on the literature analysis, which resulted in the determination of morphometric parameters, which can be calculated and determined for Lake Kisezers.

The morphometric parameters were determined in the study and are as follow: the total area of the lake and island, largest length $(\mathrm{km})$ and the largest width $(\mathrm{km})$, average width of the water body $(\mathrm{km})$, maximum depth $(\mathrm{m})$, average depth (m), shoreline length $(\mathrm{km})$, shoreline development index, volume $\left(\mathrm{m}^{3}\right)$, relative depth, volume development, deflection angles.

\section{Results and Discussion}

Lake Kisezers is a lagoon lake of origin, formed by the interaction of complex natural conditions due to the development of the Baltic Sea stages, the influence of the Gauja and Daugava rivers. Nowadays, the lake is mainly influenced and changed by anthropogenic factors. For example, according to the literature, the natural depth of Lake Kisezers should be similar to other lakes in the Seaside Lowland, but the lake due to the complex conditions of formation and anthropogenic impact since the $13^{\text {th }}$ century differs from other lakes in the Seaside Lowland. Due to its geographic location, Lake Kisezers is exposed to natural and anthropogenic factors that make the waterbody important object of studies. It is possible to simultaneously observe how the lake is affected by the catchment area, the Daugava River, Baltic Sea, City of Riga, Riga HPP and other anthropogenic effects, and to determine as in reality compared to the $20^{\text {th }}$ century. The results of research have changed perspective on morphometry and hydrological regime of the 10th largest lake in Latvia.

Since the latest bathymetric map published in the literature reflects the situation in $1932 \mathrm{~s} / 1933 \mathrm{~s}$, the construction of a new bathymetric map describing the current situation was needed. So far no Lake Kisezers bathymetric map has been constructed based on data obtained using echo sounder. The literature and internet resources have been studied prior to the field work, their analysis has been performed, and indicative data on current bathymetry information of Lake Kisezers have been found. The data was obtained from the genesimaps.com, which contains an indicative depth map. The map indicates that the depth of Lake Kisezers in the area around Milgravis Canal is not as reflected in the $20^{\text {th }}$ century bathymetric maps. The bathymetric map available at genesismaps.com cannot be used in this study due to unknown time of the map creation, water level in the lake at the time of measurements, wrongly marked coastline. The map can only be used to raise doubts as to whether the bathymetric map published so far is consistent with the current situation.

In the central part of Lake Kisezers, the depth is 4 $4.5 \mathrm{~m}$. The deepest places in Lake Kisezers were found in the immediate vicinity of Milgravis Canal and near the Jugla river in South. The deeper places are different from previous studies. They are formed as a result of sand dragging (Stiebriņš, 2011). Unfortunately, there is no information on the time of sand pumping. The 
data used to constrain the bathymetric map include 1876073 points of depth measurement.

The fieldwork data is suitable for creating a bathymetric map with isobates every $1 \mathrm{~m}$, but this map is not included in this article due to its size. The remarkable depth of the anthropogenic load has resulted in more than $15 \mathrm{~m}$ depth of sand in the deeper area. In the shore area near the depth of the shore, the shore reinforcement with piles and debris is observed, indicating the negative impact of the deepened area and the promotion of coastal erosion. The author's research results show that the maximum depth of $4.2-7 \mathrm{~m}$ as described in the literature is not true in Lake Kisezers any more. The previous information shows that Lake Kisezers deepest place was originally at the source of Milgravis Canal, where already during the L. Slaucitājs research the deepening of the anthropogenic load took place in the lake. Similarly, A. Tidrikis also points out that the deepest place was created by deepening Milgravis Canal, (Tidrikis, 1995). Thus, already in the beginning of the $20^{\text {th }}$ century, the anthropogenic influence was the main influencing factor of the Lake Kisezers morphometry and bathymetry in the south area. The deepest place of the lake is $21.5 \mathrm{~m}$. In the literature, it can be seen that the depth of the lake in the sand pumping sites exceeds $16 \mathrm{~m}$ (Stiebriņ̌š, 2011). The study reflects the true depth of the area, the results show how deep the sand has actually been pumped out. It cannot be ruled out that rapid fluctuations in the water level have contributed to the leaching of the lake bed in these underwater quarries, resulting in areas deeper today than those planned by sand miners.

In the $20^{\text {th }}$ century, L. Slaucītājs (Slaucittājs, 1935) described that the greatest depth of Lake Kisezers is $7 \mathrm{~m}$. Information in other $20^{\text {th }}$ century studies has not been reflected due to possible secrecy as Lake Kisezers was in close proximity to military complexes such as Suzi Base (National Armed ..., 2010).

Lake Kisezers has three islands with a total area of $65921.4 \mathrm{~m}^{2}$. The total area of the lake is 19.96 $\mathrm{km}^{2}$. The size of the islands and the lake is different from the literature, which explains the location of the island and the shoreline of each lake. It is assumed that in the study, the coastline would be deciphered at its real location by using a shore-based survey of shore and boat, and ice. The islands occupy the total of $0.38 \%$ of the lake area. In the encyclopedia 'Riga' it is mentioned that the lake surface area/islands area ratio is $0.44 \%$ (Kačalova, Kumsāre, \& Kundziņš, 1962). The numbers describing the length $(7.7 \mathrm{~km})$ and width $(3.14 \mathrm{~km})$ of the lake differ from the available literature. It may be that the respective numbers were incorrectly applied in previous studies. The mentioned length of $9 \mathrm{~km}$ in the literature is only possible if the line leaves the contour of the lake, which is incorrect and does not correspond to the methodological approach used nowadays, by pulling the line between the further north and south points of the lake. Due to the uneven bed, the lake volume calculations are complicated. The result proves that the volume of the lake is smaller than indicated in the literature, which most likely proves that the volume has been calculated using data when the lake has been already deepened, but the output data have not been made public. When comparing the highest water level $(2.39 \mathrm{~m}$, fixed in November 1969) and the water level during the author's bathymetric map design, the difference is $1.91 \mathrm{~m}$. The result is $33793430 \mathrm{~m}^{3}$ when calculating the volume according to the bathymetric survey data. By calculating the volume at the highest observed water level, the magnification at this water level can be up to $32229208.7 \mathrm{~m}^{3}$. Any rapid water-level fluctuations are capable of significantly affecting the volume of Lake Kisezers, and can reach up to $66022638.3 \mathrm{~m}^{3}$, which is $1 / 3$ higher than the volume indicated in the literature. It is difficult to accurately calculate the volume of a sprat as, in Lake Kisezers, strong and long-duration winds of the Northwest and Southwest direction may cause water level slips to $20-30 \mathrm{~cm}$, and this slip can last up to 10 days (Apsìte et al., 2014). In the author's study, the volume of the body of water is calculated assuming that the mirror surface of Lake Kisezers is a non-tilted plane. For the first time, the lake has an average width of $2.2 \mathrm{~km}$. The greatest depth is $21.5 \mathrm{~m}$, which differs from the literature (Hmax is 4.2 to $7 \mathrm{~m}$ ) approximately 3 to 5 times. The deepest point of the lake is found in one of the sand-pumping sites. An average depth of $1.99 \mathrm{~m}$, which is less than the value of literature, indicates that the lake has become shallower since previous studies. The length of the shoreline is $38.44 \mathrm{~km}$, which is significantly different from the $42.8 \mathrm{~km}$ mentioned in the literature. Differences can be explained by the changes caused by anthropogenic impact near the shoreline including (construction, shore reinforcement). The shore development index is 2.63 , which indicates a complex coastline. For the first time, the lake has a Relative depth of $0.98 \%$ and volume development of 0.28 , where the relative depth indicates the stratification (J.G. Tundisi \& T.M. Tundisi, 2012). Summary in Table 1.

In Lake Kisezers, the annual water level fluctuations can be observed even up to $3.17 \mathrm{~m}$, throughout the observation period from 1948 and onwards. Until 2017 the lowest observed water level fluctuation was $0.96 \mathrm{~m}$, which indicates a rapid fluctuation of water level in Lake Kisezers. This results in difficulties to characterize the morphometry of this waterbody.

Both the largest volume and the largest area are occupied by a depth area of $2-4 \mathrm{~m}$. After the bathymetric map with isobates every $1 \mathrm{~m}$ (map available on request), most areas are occupied by a 
Lake Kisezers morphometry summary from various researches

\begin{tabular}{|l|l|c|c|c|c|}
\hline \multicolumn{2}{|c|}{ Morphometric parameter } & Results & $\begin{array}{c}\text { Tidriķis, } \\
1995\end{array}$ & $\begin{array}{c}\text { Kačalova, Kumsāre \& } \\
\text { Kundziņš, 1962 }\end{array}$ & $\begin{array}{c}\text { Slaucītājs, } \\
1935\end{array}$ \\
\hline $\mathrm{f}\left(\mathrm{km}^{2}\right)$ & Area & 16.96 & 17.38 & 17.38 & 17.88 \\
\hline $\mathrm{S}\left(\mathrm{km}^{2}\right)$ & Island area & 0.065 & 0 & 0 & 0.078 \\
\hline $\mathrm{P}(\mathrm{km})$ & Maximum width & 3.14 & 3.60 & 3.60 & 3.55 \\
\hline $\mathrm{L}(\mathrm{km})$ & Length & 7.70 & 8.90 & 8.90 & 8.94 \\
\hline $\mathrm{Pv}(\mathrm{m})$ & Mean width & 2.20 & 0 & 0 & 0 \\
\hline $\mathrm{Hvid}(\mathrm{m})$ & Mean depth & 1.99 & 2.40 & 3 & 2.40 \\
\hline $\mathrm{Hmax}(\mathrm{m})$ & Maximum depth & 21.50 & 4.20 & 4.20 & 7.00 \\
\hline $1(\mathrm{~km})$ & Shoreline length & 38.44 & 42.80 & 42.80 & 42.80 \\
\hline $\mathrm{k}$ & Shore development index & 2.63 & 0 & 2.90 & 2.90 \\
\hline $\mathrm{V}\left(\mathrm{m}^{3}\right)$ & Volume & 33793429.62 & 42000000 & 40809000 & 40809000 \\
\hline $\mathrm{Zr}(\%)$ & Relative depth & 0.98 & 0 & 0 & 0 \\
\hline $\mathrm{Q}$ & Volume development & 0.28 & 0 & 0 & 1.01 \\
\hline
\end{tabular}

depth area of 3-4 m and a depth area of $2-3 \mathrm{~m}$, which proves that the bathymetric map with isobates every $2 \mathrm{~m}$ (map available on request) provides the results that are relevant to the specification. It is mentioned that the largest area occupies a depth of $1-3 \mathrm{~m}$ (Kačalova, Kumsāre, \& Kundziņš, 1962). So it can be concluded that sand mining did not take place before 1962.

Analyzing the changes in the lake coastline using historical cartographic materials, it was found that they are mainly influenced by eutrophication and anthropogenic impact. The greatest changes are seen in areas with the highest proportion of macrophytes and areas, where the anthropogenic load is observed (shore reinforcement, building, pier construction, other construction).

The main factor influencing the Kisezers morphometry and hydrological regime is the Riga HPP and its water level fluctuations, and the considerable flow rate in the Milgravis watercourse. This effect is particularly evident in volumetric and shoreline length changes.

\section{Conclusions}

1. Methodology for bathymetric map construction approves its suitability for lake survey repeatability. The research shows that using the latest technology, it is possible to perform highlevel morphometry and bathymetry studies, which result in inaccurate data on the depth and dimensions of the waterbody.
2. During the study, it was shown that the bathymetry and morphometry of Lake Kisezers had changed significantly compared to the results of previous studies. Previous studies of the Lake Kisezers morphometry have occurred irregularly. Comparing the results of the previous studies with the results of this study, discrepancies can be observed, resulting in no fixed moment when sand quarries have been created in the lake. The differences in morphometric parameters obtained from the study can be explained by both climate change and anthropogenic effects. Water level changes, the time difference (seasonality) of parameters, such as high or low water level during the depth data measurements, inaccuracy when setting them, for example, marking waterfront shoreline, using obsolete data for calculations, resolution of the cartographic material used in the study.

\section{Acknowledgments}

The research was sponsored by Riga City Council Housing and Environment Department. Echo sounding equipment was provided by boat equipment company Eholotes.lv. The author expresses sincere gratitude to the supervisors Dr. geogr., assoc. prof. Elga Apsīte and Dr. geol., assoc. prof. Ivars Strautnieks for their time, suggestions, advice and support during the research. The author appreciates and thanks to the Faculty of Geography and Earth sciences of University of Latvia employees for their advice and recommendations.

\section{References}

1. Agnieszka, E.Ł., Adam, C., \& Kurzyca, I. (2011). Dynamics of Lake Morphometry and Bathymetry Various Hydrological Conditions. Polish Journal of Environmental Studies. 20(4), 1-11.

2. Apsīte, E., Elferts, D., Zubaničs, A., \& Latkovska, I. (2014). Long-term changes in hydrological regime of the lakes in Latvia. Hydrology Research. DOI: 10.2166/nh.2013.435. 
3. Boiten, W. (2003). Hydrometry. The Netherlands: Taylor \& Francis. pp. 6-19.

4. Cabinet of Ministers Regulations No. 858. Regulations on characterization, classification, quality criteria and procedures for the determination of anthropogenic loads of surface water body types. Adopted on 19.10.2004 Cabinet of Ministers.

5. Cimdinšs, P. (2001). Limnoekologija (Limnoecology). Riga: Mācību apgāds. 1-151. lpp. (in Latvian)

6. Glazačeva, L. (2004). Latvijas ezeri un ūdenskrātuves (Lakes and reservoirs of Latvia). Jelgava: LLU Institute of Water Management and Earth Science. 7-22. lpp. (in Latvian)

7. Gilberto, F.B., Goncalves, A.M., \& da C. Garcia, F. (2014). The Morphometry of Lake Palmas, a Deep Natural Lake in Brazil. Plos One. 9(11), 1-14. DOI: 10.1371/journal.pone.0111469.

8. Hakanson, L. (1981). A Manual of Lake Morphometry. Sweden: Springer. pp. 3-72.

9. Jawak, S.D., \& Luis, A.J. (2015). Spectral information analysis for the semiautomatic derivation of shallow lake bathymetry using high-resolution multispectral imagery: A case study of Antarctic coastal oasis. Aquatic Procedia. 4, 1331-1333. DOI: 10.1016/j.aqpro.2015.02.173.

10. Kačalova, O., Kumsāre, A., \& Kundziņš, M. (1962). Lielie ezeri Rìgas apkārtnē (Great Lakes in Riga). Riga: Publishing House of Latvian Academy of Sciences. 5-11. lpp. (in Latvian)

11. Kačalova, O. (1984). K̦īšezers. In: Jērāns, P. (eds.) Latvijas Padomju enciklopēdija (Latvian Soviet Encyclopedia). Vol. 2, Riga: Main edition of encyclopaedies. 671 lpp. (in Latvian)

12. Kokorīte, I. (2007). Latvijas virszemes ūdenu ḳīmiskais sastāvs un to ietekmējošie faktori. Promocijas darbs. (The chemical composition and their influencing factors of surface waters in Latvia. Promotion paper). Rìga: University of Latvia. (in Latvian)

13. Kumsāre, A. (1960). Latvijas PSR iekšējo ūdeņu limnologisko pētījumu gaita un sasniegumi (The course and achievements of the limnological research of the internal waters of the Latvian SSR). Riga: LSSR ZA, Fisheries of Inland Waters of Latvian SSR. 8-46. lpp. (in Latvian)

14. Leinerte, M. (1992). Ezeri ainavā (Lakes in the landscape). In: A. Melluma, M. Leinerte. Ainava un cilvēks (Landscape and man). Riga: Avots. 175 lpp. (in Latvian)

15. LVG̣MC(Latvian Environment, Geology and Meteorology Centre).(2014). Bütiski ūdeņu apsaimniekošanas jautäjumi Latvijas upju baseinos (Essential water management issues in Latvian river basins). Retrieved November 20, 2017, from https://www.meteo.lv/fs/CKFinderJava/userfiles/files/Vide/Udens/Ud_apsaimn/ UBA\%20plai BUTISKI_UDENU_APSAIMNIEKOSANAS JAUTAJUMI_LATVIJA_2.pdf. (in Latvian)

16. National Armed Forces. (2010). History. Retrieved May 10, 2018, from http://www.mil.lv/lv/Vienibas/ Kajnieku_brigade/Vienibas/1_Kajnieku_bataljons/Vesture.aspx. (in Latvian)

17. Pastors, A. (1968). Ķī̌sezers. Grām.: Samsons, V. (galv. red.), Latvijas PSR Mazā Enciklopēdija (The Little Encyclopaedia of the Latvian SSR). Vol. 2, Rīga: Latvijan PSR Science Academy, Science Academy, 626 lpp. (in Latvian)

18. Sambuelli, L., \& Bava, S. (2011). Case study: A GPR survey on a morainic lake in northern Italy for bathymetry, water volume and sediment characterization. Journal of Applied Geophyzics. 81, 48-56.

19. Slaucītājs, L. (1935). Morfometriskie elementi datiem Latvijas ezeriem (Morphometric Elements for Data on Latvian Lakes). In: Bokaiders, J., Slaucītājs, L. (eds.) G̦eogrāfiskie raksti (Geographical articles). Vol. 5, Riga: Latvian Society of Geography, 134-135. lpp. (in Latvian)

20. Spuris, Z. (1968). No Latvijas ezeru pētniecības vēstures (From the history of Latvian lake research). Rīga, Latvijas Valsts Izdevniecība. 116-137. lpp. (in Latvian)

21. Stiebriņ̌̌, O. (2011). Ķī̌sezera raksturojums un eksplutācijas (apsaimniekošanas) noteikumi (Characterization of sprat and exploitation (management) regulations). Retrieved March 24, 2017, from http://www.sus.lv/sites/default/files/media/faili/kisezera_raksturojums_un_ta_ekspluatacijas noteikumi. pdf. (in Latvian)

22. Tidriḳis, A. (1995). Ķī̌sezers. In: G. Kavacs (eds.). Latvijas daba: enciklopēdija (Nature of Latvia: Encyclopedia). Vol. 3, Riga: Encyclopedia of Latvia, 67. lpp. (in Latvian)

23. Tundisi, J.G., \& Tundisi, T.M. (2012). Limnology. London: Taylor and Francis Group, pp. 2-58.

24. Сизов, Н.В. (1959). Физико-географическая характеристика некоторых озер Латвийской ССР (Physical and geographical characteristics of some lakes of the Latvian SSR). CCР, Рига: Изд. Академия Наук. Латв., 56 cc. (in Russian) 